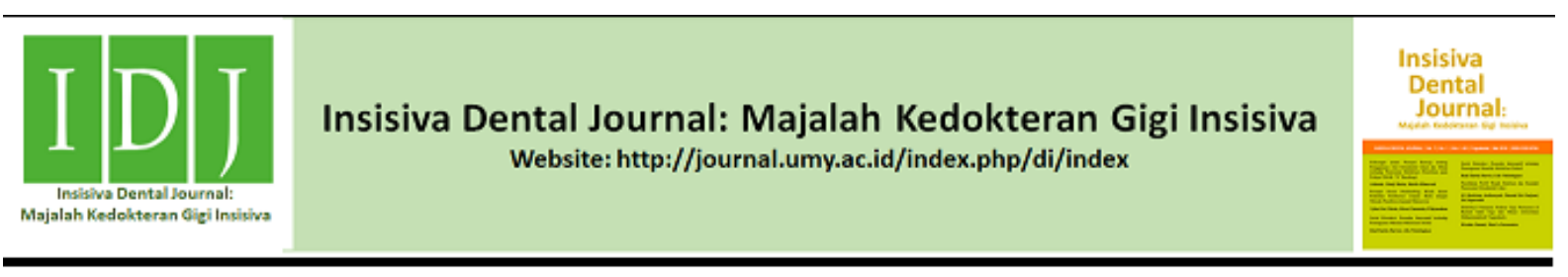

Case Report

\title{
Periodontitis Kronis dan Penatalaksaan Kasus dengan Kuretase
}

\section{Treatment of Chronic Periodontitis with Curettage}

Ika Andriani, 1,*, Firda Alima Chairunnisa ${ }^{2}$

${ }^{1}$ Departemen Periodonsia, Program Studi Kedokteran Gigi, Universitas Muhammadiyah Yogyakarta, Jalan Brawijaya, Tamantirto, Kasihan, Bantul, Indonesia.

${ }^{2}$ Program Studi Kedokteran Gigi, Universitas Muhammadiyah Yogyakarta, Jalan Brawijaya, Tamantirto, Kasihan, Bantul, Indonesia.

Received date: October $17^{\text {th }}, 2018$; reviewed date: November $4^{\text {th }}, 2018$; revised date: February $24^{\text {th }}, 2019$; accepted date: March $12^{\text {nd }}, 2019$ DOI : $10.18196 /$ di.8103

\begin{abstract}
Abstrak
Periodontitis adalah penyakit multifaktorial yang menyebabkan peradangan pada jaringan periodontal. Secara umum penyakit periodontal disebabkan oleh bakteri plak pada permukaan gigi, dimana plak berupa lapisan tipis biofilm yang berisi kumpulan mikroorganisme patogen seperti Porphyromonas gingivalis, Actinobacillus actinomycetemcomitans, Prevotela intermedia, Tannerella forsythia serta Fusobacterium nucleatum yang merupakan deposit lunak. Eliminasi bakteri dengan kuretase akan menurunkan peradangan periodontal. Tujuan laporan kasus ini adalah menjelaskan respon imun terhadap penyakit periodontitis kronis serta penatalaksanaan kasus dengan kuretase. Kasus seorang pasien laki-laki berusia 52 tahun mengeluhkan gigi kotor dan gusi sering berdarah terutama ketika menyikat giginya. Pemeriksaan intra oral gingiva memerah, tepi bulat dan mengkilap, bleeding on probing positif pada semua regio, probing depth gigi 18-16 rata-rata sebesar $5 \mathrm{~mm}$, terjadi resesi gingiva pada palatal gigi 18 sebesar $4 \mathrm{~mm}$, resesi gingiva 17 pada bagian bukal sebesar $5 \mathrm{~mm}$ dan resesi gingiva 16 pada bagian bukal sebesar $6 \mathrm{~mm}$. Hasil pengukuran Oral Hygiene Index sebesar 8,3 (kategori buruk) dan plak indeks sebesar 99\%. Pemeriksaan radiografis menunjukkan adanya kerusakan tulang alveolar arah horisontal pada gigi 15, 16, 17, 18. Penatalaksanaan kasus dilakukan scaling, root planing dan kuretase. Kesimpulan dari laporan kasus ini yaitu bakteri plak merupakan penyebab primer dari penyakit periodontal. Perawatan dengan kuretase untuk mengurangi dan menghilangkan penyebab peridontitis serta memperbaiki perlekatan dan merangsang terbentuknya perlekatan baru.
\end{abstract}

Kata Kunci: Kuretase; Peridontitis kronis

\begin{abstract}
Periodontitis is a multifactorial disease that causes inflammation of the periodontal tissue. In general, periodontal disease is caused by plaque bacteria on the tooth surface. Plaque is a thin layer of biofilm containing a deposition of pathogenic microorganisms, such as Porphyromonas gingivalis, Actinobacillus actinomycetemcomitans, Prevotela intermedia, Tannerella forsythia, and Fusobacterium nucleatum, which are soft deposits. Bacterial elimination with curettage will reduce periodontal inflammation. The purpose of this case report was to explain the immune response to chronic periodontitis and the management of the cases with curettage. The case reported a 52-year-old male patient who complained of dirty teeth and gums, which often bleeding, especially when brushing his teeth. Examination of the intraoral gingiva was red, round, and shiny edge; bleeding on positive probing in all regions; probing depth of teeth 18-16 on average by $5 \mathrm{~mm}$; gingival recession in tooth palatal 18 by $4 \mathrm{~mm}$; gingival recession 17 on the buccal part as large as $5 \mathrm{~mm}$; and 16 gingival recession in the buccal section of $6 \mathrm{~mm}$. The results of the Oral Hygiene Index measurement were 8.3 (bad category), and index plaque was 99\%. Radiographic examination showed horizontal alveolar bone damage in teeth 15, 16, 17, and 18. Management of the case was performed by scaling, root planing, and curettage. It could be concluded that plaque bacteria is the predominant factor of periodontal disease. Treatment with curettage can reduce and eliminate the causes of periodontitis, improve attachment, and stimulate the formation of new attachments.
\end{abstract}

Keywords: Curettage; Chronic Periodontitis

*Corresponding author, e-mail: ikaandriani@yahoo.com 


\section{PENDAHULUAN}

Periodontitis merupakan faktor resiko yang berperan terhadap gangguan fungsi pengunyahan dan hilangnya gigi, kelainan yang sering dijumpai dan terjadi pada manusia. ${ }^{1}$ Perawatan periodontitis dengan initial fase therapy yang terdiri dari scaling, root planing, peningkatan oral hygiene, bahkan mungkin diperlukan penyesuaian oklusal. ${ }^{2}$ Secara umum penyakit periodontal disebabkan oleh bakteri plak pada permukaan gigi, dimana plak berupa lapisan tipis biofilm yang berisi kumpulan mikroorganisme patogen seperti Porphyromonas gingivalis, Actinobacillus actinomycetemcomitans, Prevotela intermedia, Tannerella forsythia serta Fusobacterium nucleatum yang merupakan deposit lunak. ${ }^{1}$

Gingivitis dan poket gingiva terjadi karena rusaknya perlekatan gingiva (loss of gum attachment) dengan akar gigi menandakan adanya periodontitis ringan. Kerusakan jaringan karena infeksi jaringan periodontal mengandung bahan-bahan toksik (berasal dari bakteri maupun respon inflamasi). Bakteri secara langsung dapat merusak jaringan inang yang dapat menghasilkan bermacam-macam toksin (terutama protease). Respons inflamasi yang terjadi secara masif dapat merusak jaringan serta menghasilkan bahan-bahan toksik prooksidatif. Respons inflamasi menyebabkan keadaan inflamasi akut yang mengakibatkan kerusakan jaringan. ${ }^{3}$ Sedangkan kerusakan progresif ligamen periodontal dan tulang alveolar (alveolar bone loss) menyebabkan gigi goyang dan mudah tanggal menandakan periodontitis parah. Kebersihan mulut yang jelek ditandai adanya timbunan plak bakterial pada karang gigi subgingival berkorelasi positif dengan keparahan periodontitis. Inflamasi merupakan barisan pertama pada sistem pertahanan tubuh terhadap jejas bakterial. Netrofil menandakan respon fagosit terutama untuk memfagositosis dan menghancurkan antigen bakterial. Netrofil memproduksi bahan-bahan toksik prooksidatif seperti oksidan/ radikal bebas serta enzim-enzim hidrolitik dan proteolitik yang merupakan mekanisme penghancuran bakteri. Bahanbahan untuk membunuh bakteri ini juga dapat merusak molekul-molekul inang dan menyerang dan di sekitar daerah inflamasi. ${ }^{3}$ Netrofil sebagai respons terhadap infeksi bakteri menghasilkan bahan-bahan toksik prooksidatif sebagai berikut. 1. Reactive oxygen species (ROS), berupa radikal bebas dan oksidan, seperti asam hipoklorit $(\mathrm{HOCl})$, radikal superoksid $\left(\mathrm{O}^{2-}\right)$, radikal hidroksil $\left(\mathrm{OH}^{-}\right)$, hidrogen dan peroksida $\left(\mathrm{H}_{2} \mathrm{O}_{2}\right)$. Bahan yang bersifat toksik ditujukan untuk mengoksidasi molekul bakterial. 2. Fosfatase, proteolitik dan glukorodinase, lipase dan arilsulfatase merupakan enzim-enzim yang berasal dari lisosom. Asam nukleat, fosfolipid, dan senyawa-senyawa yang mengandung fosfat pada bakteri diserang oleh enzim fosfatase. Enzim proteolitik menghidrolisis glukoprotein bakteri seperti katepsin dan lisozim. Glukoronidase memiliki peran untuk mencerna karbohidrat. Lipase berperan untuk mencerna lipid dan yang dapat menghancurkan senyawa aromatik mengandung sulphur pada bakteri merupakan enzim arilsulfatase. 3. Metal ( $\mathrm{Zn}$ ) yaitu enzim matrix metalloproteinases (MMPs) terkandung dalam enzim proteinase. Mediator proinflamatori (IL-1 dan $\mathrm{TNF} \alpha$ ) yang menginduksi produksi MMPs dihasilkan oleh netrofil yang merupakan stimulasi bakterial. Enzim utama penghancur matrik ekstraselular yang utamanya tersusun atas kolagen merupakan MMPs. ${ }^{3}$

Adanya poket sering menandakan sebagai adanya penyakit periodontal. Proses bertambah dalamnya sulkus gingiva merupakan definisi poket periodontal dan gambaran klinis dari penyakit periodontal. ${ }^{2}$ Kuretase tertutup dan flap kuretase merupakan prosedur untuk menghilangkan faktor-faktor etiogenik pada poket periodontal untuk menghilangkan adanya lesi. Jaringan patogen dan debris yang berada dalam poket periodontal harus segera dihilangkan sehingga tidak meluas 
menjadi lebih parah. Kuretase merupakan perawatan alternatif poket periodontal. ${ }^{2}$ Tujuan laporan kasus ini adalah menjelaskan respon imun terhadap penyakit periodontitis kronis serta penatalaksanaan kasus dengan kuretase.

\section{LAPORAN KASUS}

Seorang pasien laki-laki berusia 52 tahun datang ke Rumah Sakit Gigi dan Mulut Universitas Muhammadiyah Yogyakarta mengeluhkan giginya terasa kasar dan kotor terutama pada gigi depan bawahnya. Keluhan tersebut di rasakan sejak kurang lebih 1 tahun yang lalu. Pasien belum pernah datang kedokter gigi untuk melakukan perawatan dan pembersihan karang gigi. Pasien pernah mengeluhkan gusinya mudah berdarah ketika sikat gigi. Pasien menyikat gigi 2 kali sehari pada pagi dan sore hari namun cara menyikat gigi pasien masih salah.

Berdasarkan dari anamnesa yang telah dilakukan diketahui bahwa pasien tidak mempunyai riwayat penyakit sistemik. Pada pemeriksaan intraoral terdapat gingiva berwarna kemerahan, papila interdental membulat, tekstur unstippling, konsistensi lunak pada gingiva posterior bukal dan lingual rahang bawah, serta pada gingiva anterior palatal dan posterior bukal dan palatal rahang bawah, bleeding on probing positif pada semua regio, probing depth gigi 18-16 rata-rata sebesar $5 \mathrm{~mm}$, terdapat resesi gingiva pada bagian bukal gigi 18 sebesar $4 \mathrm{~mm}$, resesi gingiva 17 pada bagian bukal sebesar $5 \mathrm{~mm}$ dan resesi gingiva 16 pada bagian bukal sebesar $6 \mathrm{~mm}$. Hasil pengukuran Oral Hygiene Index sebesar 8,3 (kategori buruk) dan Plak indeks sebesar 99\%. Pemeriksaan radiografis menunjukkan adanya kerusakan tulang alveolar arah horisontal pada gigi 15, $16,17,18$.

Diagnosis klinis kasus diatas adalah periodontitis kronis. Prognosis baik karena pasien tidak memiliki riwayat penyakit sistemik, pasien memiliki motivasi yang tinggi untuk menjaga kebersihan rongga mulutnya dan kooperatif.

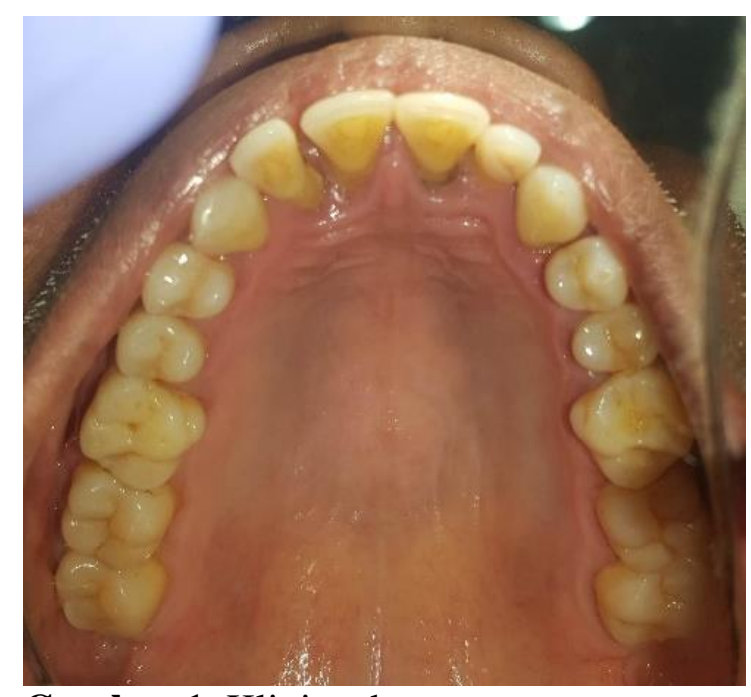

Gambar 1. Klinis rahang atas.

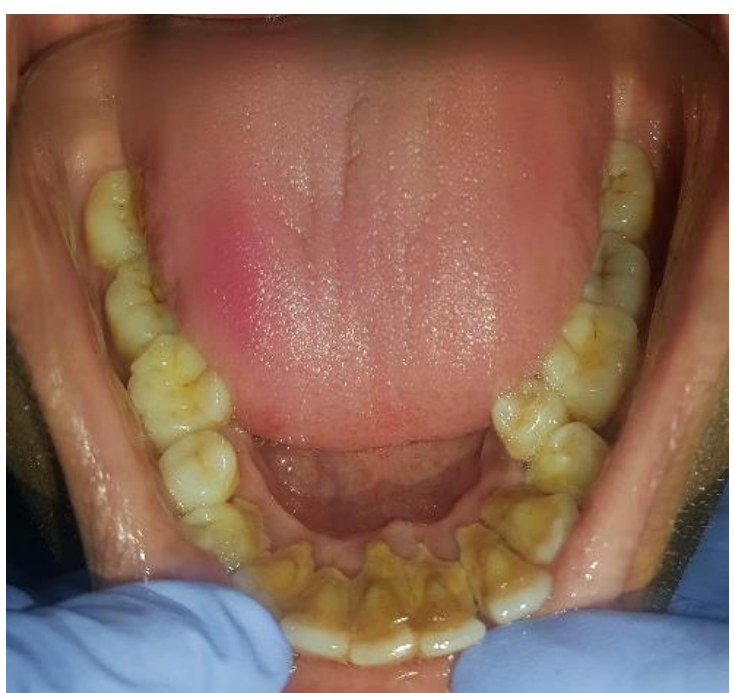

Gambar 2. Klinis rahang bawah.

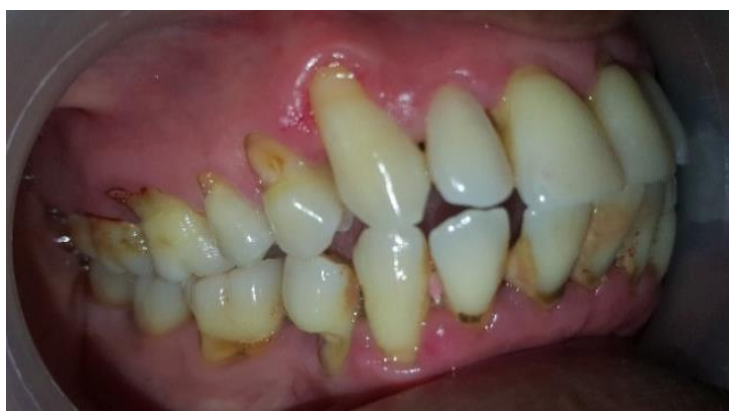

Gambar 3. Klinis samping.

Dari hasil pemeriksaan yang telah dilakukan terdapat gingiva berwarna kemerahan, mudah berdarah, hasil pengukuran Oral Hygiene Index sebesar 8,3 (kategori buruk) dan Plak indeks sebesar 99\%. Sehingga pada kunjungan pertama dilakukan skeling supragingiva, subgingiva 
dan root planing. Setelah dilakukan skeling kemudian dilakukan kuretase tanpa menggunakan anestesi lokal, kuretase dilakukan dengan menggunakan kuret gracey berwarna putih untuk permukaan bukal dan lingual gigi premolar dan molar, kuret gracey berwarna hitam untuk permukaan mesial gigi posterior dan kuret gracey berwarna coklat untuk permukaan distal gigi posterior. Cara menggunakan kuret gracey yaitu masukkan kuret kedalam sulkus gingiva searah aksis gigi sampai dasar poket, dan bagian yang tajam dari kuret gracey diletakkan pada daerah epitel sulkuler, kemudian lakukan pengerokan beberapa kali sampai jaringan granulasi terangkat semua dan tidak terdapat jaringan granulasi lagi.

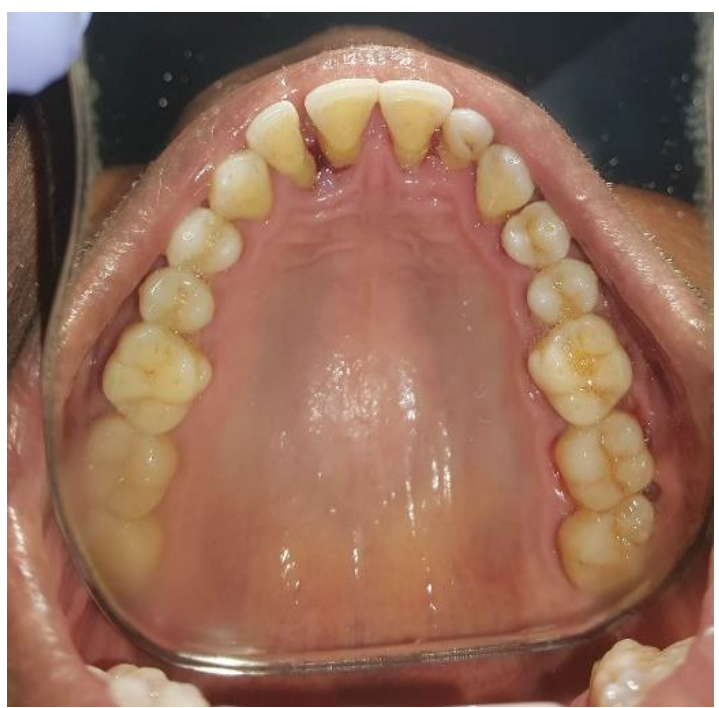

Gambar 4. Paska scalling dan kuretase.

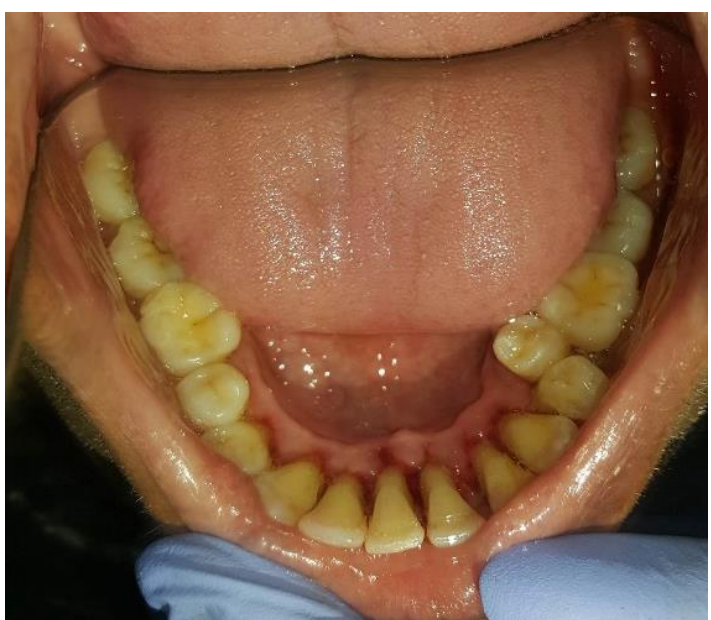

Gambar 5. Paska scalling dan kuretase RB
Kemudian dilakukan irigasi dengan menggunakan povidon iodin dan salin. Pasien diedukasi untuk menjaga kebersihan rongga mulutnya dengan cara menggosok gigi minimal 2 kali sehari setiap pagi dan malam hari sebelum tidur, berkumur setiap selesai makan, makan - makanan yang bergizi dan perbanyak makan buah serta kontrol 2 minggu paska dilakukan perawatan.

Pada saat dilakukan kontrol yaitu 2 minggu setelah dilakukan perawatan pasien sudah tidak ada keluhan gusi mudah berdarah, dan pasien merasa lebih nyaman setelah dilakukan perawatan. Dari pemeriksaan intraoral terdapat perbaikan gingiva berwarna merah muda, papila interdental runcing, tekstur stippling, konsistensi kenyal, pada gingiva anterior labial rahang atas, serta terdapat perbaikan gingiva posterior bukal kanan rahang atas. Hasil pengukuran Oral Hygiene Index sebesar 2,1 (kategori baik) dan Plak indeks mengalami penurunan yaitu dari $99 \%$ menjadi $72 \%$.

\section{PEMBAHASAN}

Periodontitis disebabkan oleh bakteri yang merupakan penyakit infeksi pada jaringan penyangga gigi. Periodontitis juga menyebabkan kerusakan tulang alveolar, ligamen periodontal, sehingga membentuk poket, menyebabkan resesi atau keduanya. ${ }^{4}$ Penyakit periodontal sendiri memiliki etiologi dan patogenesis yang multifaktorial, adanya bakteri patogen yang berperan tidak cukup menyebabkan terjadinya kelainan. ${ }^{5}$

Periodontitis kronis disebabkan oleh bakteri gram negatif, bakteri anaerob dan bakteri mikroaerofilik yang terdapat pada daerah subgingiva dan menyebabkan adanya prostat prostaglandin pro-inflamasi dan sitokinin yang mengakibatkan terjadinya kerusakan pada jaringan periodontal. ${ }^{6}$ Bakteri patogen penyebab terjadinya penyakit periodontal seperti Aggregatibacter actinomycetemcomitan Treponemadenticola, dan Tannerella 
forythia dapat mengakibatkan terjadinya inflamasi pada jaringan periodontal. ${ }^{7,8}$

Respon imun dan inflamasi yang datang penting dalam perkembangan penyakit periodontal bersifat merusak jaringan dan juga dipengaruhi oleh lingkungan, faktor genetik dari penderita dan pola hidup. ${ }^{9}$ Sistem imun bertujuan melindungi integritas dan individu serta mencegah invasi organisme dan zat yang berbahaya di lingkungan yang dapat merusak dirinya yang merupakan sistem koordinasi respons biologi. ${ }^{10}$

Bakteri plak merupakan penyebab primer dari penyakit periodontal. Hasil dari produk bakteri dapat mengubah metabolisme dan menghambat pertumbuhan dari jaringan sel inang. Sistem imun melibatkan interaksi yang kompleks antara molekul regulasi dan sel. Kerusakan jaringan diakibatkan oleh produk-produk dari bakteri.

Sel darah putih atau leukosit mempunyai peranan penting terhadap respons keradangan. Setiap bahan infeksius yang mungkin ada, leukosit menyediakan pertahanan yang kuat dan cepat. Pada infeksi yang disebabkan bakteri maupun mikroba lain yang infeksius dan toksik, dapat dijumpai peningkatan leukosit. Pada radang akut leukosit yang berperan yaitu neutrofil dan monosit, sedangkan pada radang kronik yang berperan yaitu makrofag dan limfosit.

Neutrofil merupakan pertahanan awal saat terjadinya inflamasi, yang menyebabkan peningkatan pada jumlah neutrofil. Peranan neutrofil sangat penting dalam mekanisme pertahanan terhadap infeksi bakterial. Neutrofil merupakan fagosit utama terhadap bakteri ekstraseluler dalam sistem pertahanan tubuh. peningkatan neutrofil, terjadi karena adanya peradangan yang disebabkan oleh infeksi bakteri. Neutrofil polimorfonuklear merupakan sel pertama yang muncul dalam jumlah besar pada jam pertama terjadinya peradangan. Hal ini disebabkan karena neutrofil terdapat dalam jumlah banyak dalam sirkulasi darah dan juga adanya mobilitasnya yang tinggi. Selain itu, pada awal reaksi radang yang telah aktif, neutrofil merupakan faktor yang mempengaruhi. Dengan proses yang disebut fagositosis, neutrofil memiliki kemampuan untuk bergerak aktif seperti amoeba dan mampu menelan berbagai zat. Proses fagositosis dibantu oleh zat-zat opsonin tertentu yang membuatnya lebih mudah dimasukkan oleh leukosit dan melapisi obyek untuk dicernakan. ${ }^{11}$

Mekanisme terjadinya pertahanan tubuh untuk melawan bakteri pada plak gigi dan yang terdapat pada epithelium junctional dan sulkus gingiva adalah ketika neutrofil mengeluarkan enzim lisosom dan granulasi seperti lisozim, elastase, kolagenase, myeloperoxidase selama terjadi fagositosis atau setelah nekrosis sehingga menyebabkan kerusakan jaringan sekitar. ${ }^{12}$

Perawatan periodontitis kronis dengan kedalaman poket $5 \mathrm{~mm}$, keadaan jaringan terinflamasi, non fibrotik, oedematous, kontur gingiva membulat seperti kasus diatas dilakukan perawatan kuretase untuk menangani keadaan tersebut. Perawatan kuretase bertujuan untuk mengurangi dan menghilangkan terjadinya poket periodontal serta memperbaiki perlekatan dan merangsang terbentuknya perlekatan baru. ${ }^{13}$ Prosedur perawatan kuretase dilakukan menggunakan kuret gracey untuk gigi posterior, bagian yang tajam dari kuret gracey di arahkan pada daerah epitel sulkuler kemudian dilakukan pengerokan pada sepanjang jaringan lunak sehingga jaringan granulasi seperti fibroblastik dan proliferasi angioblastik, serta kalkulus yang berisi akumulasi bakteri dapat terangkat. ${ }^{2}$ Setelah dilakukan perawatan kuretase akan terjadi proses perbaikan pada epitel sulkuler yang berlangsung antara 2 sampai 7 hari, sedangkan untuk perbaikan epitel cekat terjadi selama 5 hari, pengerutan margin gingiva terjadi selama 1 minggu dan penyembuhan sempurna terjadi antara 2 minggu atau 3 minggu setelah kuretase. Penyembuhan tersebut dipengaruhi oleh 
beberapa faktor seperti faktor sistemik, sistem kekebalan tubuh pasien, dan kepedulian pasien untuk menjaga kebersihan rongga mulutnya. ${ }^{13}$

\section{KESIMPULAN}

Bakteri plak merupakan penyebab primer dari penyakit periodontal. Penyakit periodontal sendiri memiliki etiologi dan patogenesis yang multifaktorial, adanya bakteri patogen yang berperan tidak cukup menyebabkan terjadinya kelainan. Pada infeksi yang disebabkan bakteri maupun mikroba lain yang infeksius dan toksik, dapat dijumpai peningkatan leukosit. Pada radang akut leukosit yang berperan yaitu neutrofil dan monosit, sedangkan pada radang kronik yang berperan yaitu makrofag dan limfosit.

Penanganan periodontitis kronis dengan melakukan perawatan kuretase bertujuan untuk mengurangi dan menghilangkan terjadinya poket periodontal serta memperbaiki perlekatan dan merangsang terbentuknya perlekatan baru.

\section{DAFTAR PUSTAKA}

1. Ermawati, Tantin. Periodontitis dan Diabetes Melitus. Stomatognatic. J.K.G Unej. 2012; 9(3): 152 - 154.

2. Dinyati, M., Andi M A. Kuretase Gingiva Sebagai Perawatan Poket Periodontal. Makassar Dent J. 2016; 5(2): 58-64.

3. Susilawati, I Dewa Ayu. Periodontal infection is a "Silent Killer". Stomatognatic. J.K.G Unej. 2011; 8(1): 21-26.

4. Carranza, FA. Clinical Periodontology. Edisi ke-9. Philadelphia: WB Saunders. Pp160183, 2006; 349-350.

5. Kuswandani, O. Sandra. Academic Stress Influences Periodontal Health Condition and Interleukin-1 beta Level. Journal of Dentistry Indonesia, 2014; 21(1): 16-20.

6. Armitage, GC. Periodontal Diagnoses And Classification of Periodontal
Diseases. Periodontology, 2000; 34: 921.

7. Gumus, Pinar. The Role of TLRs in The Pathogenesis of Periodontal Diseases. Journal of Dental Science and Therapy, 2016; 1(1): 3-6.

8. Hajishengallis, G., John, DL. Microbial Manipulation of Receptor Crosstalk in Innate Immunity. National Institute of Health, 2011; 11(3): 187200.

9. Ekaputri, S \& Masulili, S.L.C. Cairan Sulkus Gingiva sebagai Indikator Keadaan Jaringan Periodontal. Maj Ked.Gr., 2010; 17(1): 81-86.

10. Munasir, Z., Respons Imun terhadap Infeksi Bakteri. Sari Pediatri, 2001; 2(4): $193-197$.

11. Nuarita, R., Praharani, D., Kusumawardani, B., Pengaruh Penyakit Periodontal Selama Masa Kehamilan terhadap Jumlah Total Leukosit dan Hitung Jenis Leukosit. Stomatognatic J.K.G Unej, 2012; 9 (3): $125-130$.

12. Kornman, KS. Mapping The Pathogenesis of Periodontitis: A New Look. J Periodontol. 2008; 79(8): 1560-1568.

13. Witjaksono, W., Roselinda, A., TP, Kannan. Clinical Evaluation in Periodontitis Patient After Currettage. Dent J (Majalah Kedokteran Gigi), 2006; 39(3): 102-106. 